\title{
Lesioning of the Striatum Reverses Motor Asymmetry in the 6-Hydroxydopamine Rodent Model of Parkinsonism
}

\author{
G.M. Friehs ${ }^{1}$, R.G. Parker ${ }^{1}$, L.S. He ${ }^{1}$, S.J. Haines ${ }^{1}$, \\ D.A. Turner ${ }^{1,3}$, and T.J. Ebner ${ }^{1,2,3}$ \\ Departments of Neurosurgery ${ }^{1}$ and Physiology ${ }^{2}$ \\ and The Graduate Program in Neuroscience ${ }^{3}$ \\ University of Minnesota, Minneapolis, MN, USA
}

\begin{abstract}
Present address of
Dr. D.A. Turner:

Box 3807, Neurosurgery

Duke University Medical Center

Durham, N.C. 27710, USA

Reprint address:

Dr. Timothy J. Ebner

University of Minnesota

Dept. of Neurosurgery

Box 96, UMHC

420 Delaware St. S.E.

Minneapolis, MN 55455

USA
\end{abstract}

ABSTRACT

In the rat several paradigms of grafting of adrenal medulla into the striatum were studied following the induction of a parkinsonian model, using a unilateral 6-hydroxydopamine (6-OHDA) lesion of the substantia nigra. Direct autologous grafting of adrenal medulla into the caudate-putamen complex, a radiofrequency lesion of the striatum alone, and a radiofrequency lesion followed by delayed grafting of adrenal medulla were compared by analyzing rotational behavior. Direct grafting of adrenal medulla produced an overall reduction in apomorphine induced turning behavior by $43.5 \%$ when compared with controls. Radiofrequency lesioning of the striatum without graft showed the best improvement over control

VOL. 2, NO. 2, 1991 animals with a $92 \%$ reduction in the total number of rotations induced by apomorphine. Delayed grafting into the caudate lesion cavity also produced a dramatic reduction in motor asymmetry but did not improve the behavioral outcome over that of the lesion alone. Animals receiving only radiofrequency lesions exhibited a band of increased tyrosine hydroxylase like immunoreactivity bordering the lesion cavity. Graft survival was limited in the nonlesioned animals but appeared enhanced in the animals whose striatum was previously lesioned. Lesion location within the striatum influenced the behavioral outcome. Large reductions in apomorphine-induced rotations could result from small lesions of the dorso-lateral striatum. These findings indicate that selective destruction of the caudate-putamen complex without tissue transplantation produces a dramatic reduction in the motor asymmetry of 6-OHDA treated rats. Suggested explanations for the decrease in induced rotational behavior with radiofrequency lesions include a decrease in the number of striatal dopamine receptors following cell destruction and lesioninduced recovery of host dopaminergic afferents. Striatal damage in critical areas can reverse some of the motor behavior associated with the 6-OHDA model and needs to be considered when evaluating the effects of neural grafting in this model. 


\section{KEY WORDS}

Apomorphine, Neural Graft, Caudate-Putamen, Radiofrequency Lesion, Adrenal Medulla, Rotational Behavior, Substantia Nigra

\section{INTRODUCTION}

Chemical destruction of the dopaminergic cells of the substantia nigra with 6-hydroxydopamine (6-OHDA) has been developed as a rodent model of parkinsonism over a number of years $/ 5,21,39,49,51 /$. The dopaminergic deficit produced by the lesion remains stable for several months; lesioned rats show no recovery in their rotational behavior if $90 \%$ or more of the dopaminergic neurons in the substantia nigra pars compacta are destroyed $/ 14,20,36 /$. This model has played a central role in the evaluation of changes in motor dysfunction following transplantation of catecholamine producing cells. Transplantation paradigms into the striatum have included grafting fetal mesencephalon $/ 5,9,19,22,45,46 /$, pheochromocytoma (PC12) cells /4/, sympathetic neurons $/ 29 /$, sciatic nerve $/ 41 /$, fetal adrenal chromaffin cells $/ 30 /$, modified cultured cells $/ 24 /$, and adrenal medulla $/ 4,19,20,22,28,36,37,40,41,47,48 /$. All these grafting paradigms have yielded some level of success in reducing either amphetamine or apomorphine induced turning behavior in this model.

A variety of mechanisms by which grafting of catecholamine producing cells could enhance motor function has been discussed $/ 6,7,19,25 /$. One proposed mechanism of graft functioning indicates that the implanted tissue chronically releases dopamine, which subsequently diffuses freely within the striatum and binds to dopamine receptors $/ 3,28,47 /$. Although a tonic release mechanism requires a functioning graft, it does not necessarily indicate that the transplant has become anatomically and physiologically integrated into the host. It has also been argued that transplanted neurons, in particular fetal mesencephalic neurons, become integrated into the host striatum (see $/ 6,7 /$ ). It has also been proposed that the transplanted adrenal medullary cells transform and differentiate into dopaminergic neurons, developing neuronal-like processes and synaptic contacts with the host striatum /36/. Another hypothesis is that the graft releases or induces the production of trophic factors which may induce regrowth of damaged host dopaminergic neurons or terminals $/ 2,8,17,25,33 /$. An additional possibility that should be considered is that disruption of the target site by the graft may partly reduce the motor abnormalities, perhaps through a disconnection or lesion effect $/ 12,17$; see also $6 /$.

The grafting of adult adrenal medulla into the striatum decreased rotational behavior in several studies utilizing the 6-OHDA model $/ 4,20,21,28,36$, $47,48 /$. These observations were cited in support of recent attempts to transplant adrenal medulla homografts for human parkinsonism /1,32,33/. However, the reduction in rotational behavior with adrenal medulla grafts, particularly from older donors, is less dramatic than that observed following the grafting of fetal substantia nigra tissue $/ 5,9,19,22,45 /$. Immunohistochemical techniques have documented only limited cell survival following adult adrenal medulla grafting $/ 36,37 /$, while transplanted fetal tissue appears to survive much better in vivo (see /7/). The improved functional recovery observed with grafted fetal substantia nigra may be due to the increased resistance to anoxia of fetal tissue, increased cell survival with cell suspension grafts, or better integration into the CNS of primitive dopaminergic neurons as compared to grafted adrenal medulla. Adrenal medullary graft survival has also been limited in the MPTP primate model $/ 11 /$, compared to fetal substantia nigra implants $/ 2,17,35,43 /$.

Augmentation of the survival and integration of adrenal medulla grafts into a lesioned host is desirable. Previous attempts at enhancing graft survival have included providing exogenous nerve growth factor (NGF) via a constant infusion $/ 46 /$ as well as cografting with other neural tissue $/ 4,25,41 /$. Several studies have shown that creating a cavity or lesion within the central nervous system prior to grafting (by several days) also enhances the survival of tissue transplanted $/ 5,44 /$. One consequence of the cavity is to promote vascular ingrowth into the region, assuring a rich blood supply for the graft /44/. In response to the injury the brain may also supply growth factors (see $/ 13 /$ ). In the present report, radiofrequency lesioning of the caudate nucleus was used to create a cavity for the subsequent placement of adult adrenal medullary heterografts. Our goal was to assess the efficacy of creating a stereotaxic lesion in the striatum 
on enhancement of adrenal medullary graft survival and behavioral function. The production of a lesion without subsequent grafting, direct grafting, and delayed grafting at 14 days into the lesion cavity were all compared. Somewhat unexpectedly, lesioning the striatum by itself resulted in a dramatic reduction in apomorphine induced turning behavior, as reported previously in abstract form $/ 23 /$.

\section{MATERIALS AND METHODS}

\section{6-OHDA Lesion and Behavioral Testing}

The study was based on a $2 \times 2$ factorial design. Sixteen rats (Sprague-Dawley, 250-300 g) were divided into four equal groups: a control group (group I) that received only 6-OHDA lesions, a transplantation group (group II or graft group) that received heterografts of adrenal medulla five weeks after lesioning with 6OHDA, a caudate group (group III or RF-group) that underwent radiofrequency-lesioning five weeks following 6-OHDA, and a caudate lesion plus transplantation group (group IV or RF+graft group) that underwent adrenal medulla transplantation surgery two weeks following radiofrequency lesioning at the same site. All animals were randomly allocated into each group and followed for equal periods of time after the initial 6-OHDA lesion. The number of animals in each of the four groups was statistically based on an estimated $25 \%$ reduction in rotational behavior following adrenal medulla grafting as previously reported in the literature /4,18-20,36,48/. Means were compared with Student's t-test.

Prior to each surgical procedure, the animals were anesthetized with a cocktail containing ketamine, acepromazine and xylazine after premedication with $0.3 \mathrm{ml}$ atropine and $50 \mathrm{mg}$ ampicillin. This technique assured a surgical level of anesthesia for approximately two hours. Each operation was performed aseptically. The right nigro-striatal dopaminergic pathway was destroyed using the technique of Ungerstedt /49-51/ by a single injection of $8 \mu \mathrm{g}$ of 6-OHDA in $4 \mu \mathrm{l}$ saline with $0.2 \mathrm{mg} / \mathrm{ml}$ ascorbic acid. The 6-OHDA was injected over five minutes with a Hamilton syringe placed at the following coordinates: $4.8 \mathrm{~mm}$ posterior to bregma, $2.0 \mathrm{~mm}$ lateral and $8.1 \mathrm{~mm}$ below the surface of the dura; incisor bar at $\mathbf{- 3 . 9} \mathbf{~ m m}$ (according to the atlas of Paxinos and Watson, 1986). After the injection, the needle was left in place for an additional minute and then carefully withdrawn.

Beginning ten days after the 6-OHDA injection, the animals were then tested for rotational behavior once a week for three weeks with a low dose of apomorphine $(0.05 \mathrm{mg} / \mathrm{ml}$, Sigma Chemical Co.; $/ 5$, $48 /$ ). Rotational behavior was quantified in a rotometer consisting of a plexiglass cylinder $25 \mathrm{~cm}$ in diameter and $30 \mathrm{~cm}$ high. While in the rotometer, the animals were attached via a harness around their chest to a low friction potentiometer, which was free to rotate $360^{\circ}$ and was mounted on the top of the cylinder. The angular displacement of the potentiometer was digitized by a laboratory computer and this value was used to determine the number and orientation of the rotations during 60 minutes. Only rats with the typical biphasic rotational behavior pattern were included in this study /27,49-51/.

\section{Adrenal Medullary Transplantation and Radiofrequency Lesions}

Based on the technique described by Stromberg /48/, one complete adrenal gland was removed from the anesthetized adult donor rat (Sprague-Dawley, 200$300 \mathrm{~g}$ ) and immediately placed in a petri dish filled with ice cold lactated Ringers solution. The adrenal medulla was dissected free from the cortex under a stereomicroscope, cut into two to eight pieces and aspirated into an 18-gauge Pasteur glass pipette. The graft pieces were placed at two different sites (coordinates: $1.5 \mathrm{~mm}$ anterior, $2.0 \mathrm{~mm}$ lateral, $5.0 \mathrm{~mm}$ deep and $0.0 \mathrm{~mm}$ anterior, $4.0 \mathrm{~mm}$ lateral, $5.0 \mathrm{~mm}$ deep). Equal amounts of adrenal medulla were then pushed out of the pipette using a trocar until no tissue could be detected in the glass pipette. Each animal received one half of an adrenal medulla per site. To demonstrate that only chromaffin cells were transplanted, several tissue fragments were examined immunohistochemically for tyrosine-hydroxylase staining (see below).

Lesioning was carried out in groups II and IV. Using a radiofrequency lesion generator, a total of six lesions was placed at two different sites throughout the caudate-putamen complex (coordinates of the anterior site: $1.5 \mathrm{~mm}$ anterior to bregma, $2.0 / 2.3 / 2.6 \mathrm{~mm}$ lateral, $5.0 \mathrm{~mm}$ below the surface of the dura; 
posterior site: $0.0 \mathrm{~mm}$ anterior, $3.7 / 4.0 / 4.3 \mathrm{~mm}$ lateral, $5.0 \mathrm{~mm}$ deep). At each location the radiofrequency probe (outer diameter: $0.75 \mathrm{~mm}$ ) was heated to $55^{\circ} \mathrm{C}$ for two minutes. Ten days after producing the caudate lesion, the animals in group IV also underwent adrenal medullary grafting into the cavity using the same technique as described above.

\section{Histological Analysis and Immunohistochemistry}

After a behavioral testing and observation period of eight weeks, the animals were sacrificed under deep anesthesia and underwent intracardiac perfusion with approximately $250 \mathrm{ml}$ normal saline followed by $500 \mathrm{ml}$ Zamboni's solution (8\% paraformaldehyde phosphate buffered solution with saturated picric acid). The brain was then removed and stored in Zamboni's solution for at least four hours, followed by sucrose phosphate buffered solution (5\% sucrose in $0.1 \mathrm{M}$ PBS) for at least 12 hours. The brains were frozen in liquid nitrogen, warmed up in dry ice for 20 minutes before $10 \mu \mathrm{m}$ sections were cut on a cryostat. The sections were mounted onto gelatin and chromocarbonate covered glass slides cooled down to cryostat temperature. The sections were dehydrated by air drying. The slides were incubated with a monoclonal tyrosine-hydroxylase primary antibody (Boehringer Mannheim, FRG) for 12 hours at $4^{\circ} \mathrm{C}$ and then for another hour with the secondary, FITC labeled antibody at room temperature. To prevent photobleaching, the slides were covered with a phenylenediamine containing glycerol solution. This procedure insured long lasting stains and little change in the intensity of fluorescence. In addition, adjacent slides were used for hematoxylin-eosin staining as a control and aid in evaluating lesion size.

\section{RESULTS}

\section{Rotational Behavior}

The counterclockwise rotational behavior for each of the four groups prior to any treatment was similar, as shown in Fig. 1. The average time course of the induced apomorphine rotations is depicted in Fig. 1A, with each curve representing the mean of three pretreatment trials. Note that even for the averaged data, the biphasic rotational patterns are evident, especially in the control and graft groups. The total number of rotations prior to any treatment was not statistically different for the groups (Fig. 1B, p > 0.05, Student's ttest). The average pretreatment total number of rotations for the four groups were $483 \pm 233$ (control), $376 \pm 114$ (graft), $375 \pm 116$ (RF) and $353 \pm 118$ (RF and graft). The pretreatment rotational behavior shows that the four groups were directly comparable.

At three weeks following the various treatments, the rotational behavior changed significantly (Fig. 2). The control group continued to rotate on challenge with apomorphine with a time course and magnitude similar to the pretreatment period (as in Fig. 1A). In the animals grafted with adrenal medulla without the radiofrequency lesion, there was a decrease in the number of rotations and also a change in the time course of rotations. In the control group at three weeks (Fig. 2A) as well as in the pretreatment time period for all the other groups (Fig. 1A), the rotations began to decrease at 30 minutes and were usually absent by 40 minutes. The animals with adrenal medulla grafts exhibited a tendency towards prolongation of the duration of rotation after the induction with apomorphine (Fig. 2A, 3, and 4). Although there was a large reduction in rotations over the first 30 minutes when compared with the control (92\%), the prolongation of the rotations partially reversed this reduction. The net result was only a 35\% reduction in the total number of rotations. Surprisingly, both the RF-lesioned and RF-lesioned plus graft groups exhibited almost complete suppression of the apomorphine induced rotations at three weeks. As seen in the plots of total number of rotations (Fig. 2B), there was an $89.1 \%$ and $84.6 \%$ decrease in rotations, respectively $(\mathrm{P}<0.001$ for both groups, Student's t-test), for the RF-lesioned and RFlesioned plus graft groups. The reduction in the total number of rotations was less marked in the graft alone group. This was in part due to the prolongation of the turning behavior in the grafted animals, which contributed to the lack of significance over the control group.

These initial changes in rotational behavior, first tested at three weeks, also persisted at five weeks (Fig. 3) and seven weeks (Fig. 4). The non-treated group continued to exhibit strong rotational behavior and a biphasic profile was evident at both five and seven weeks. There was no statistical difference 


\section{BEFORE TREATMENT}

A

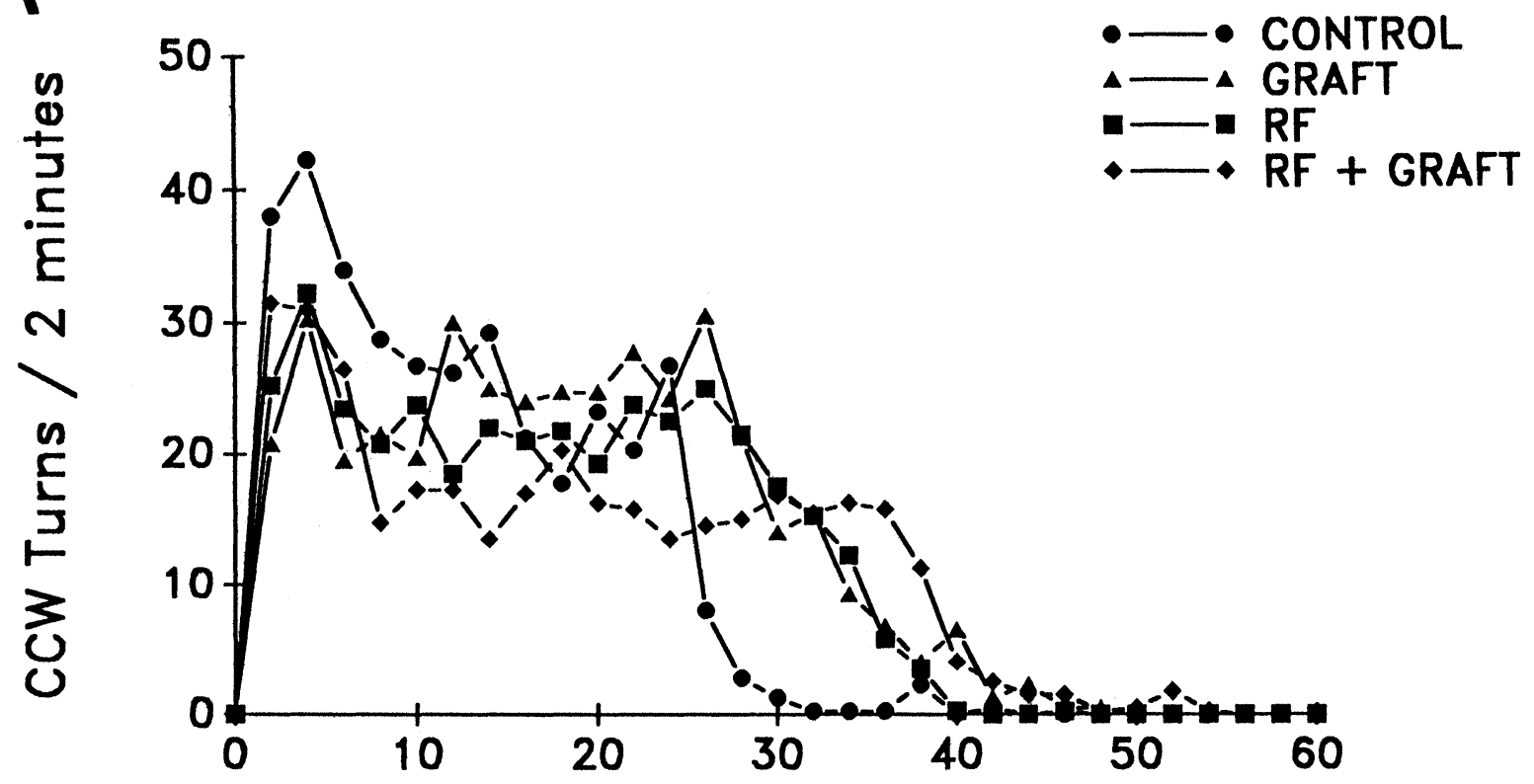

$\mathrm{B}$

Time (minutes)

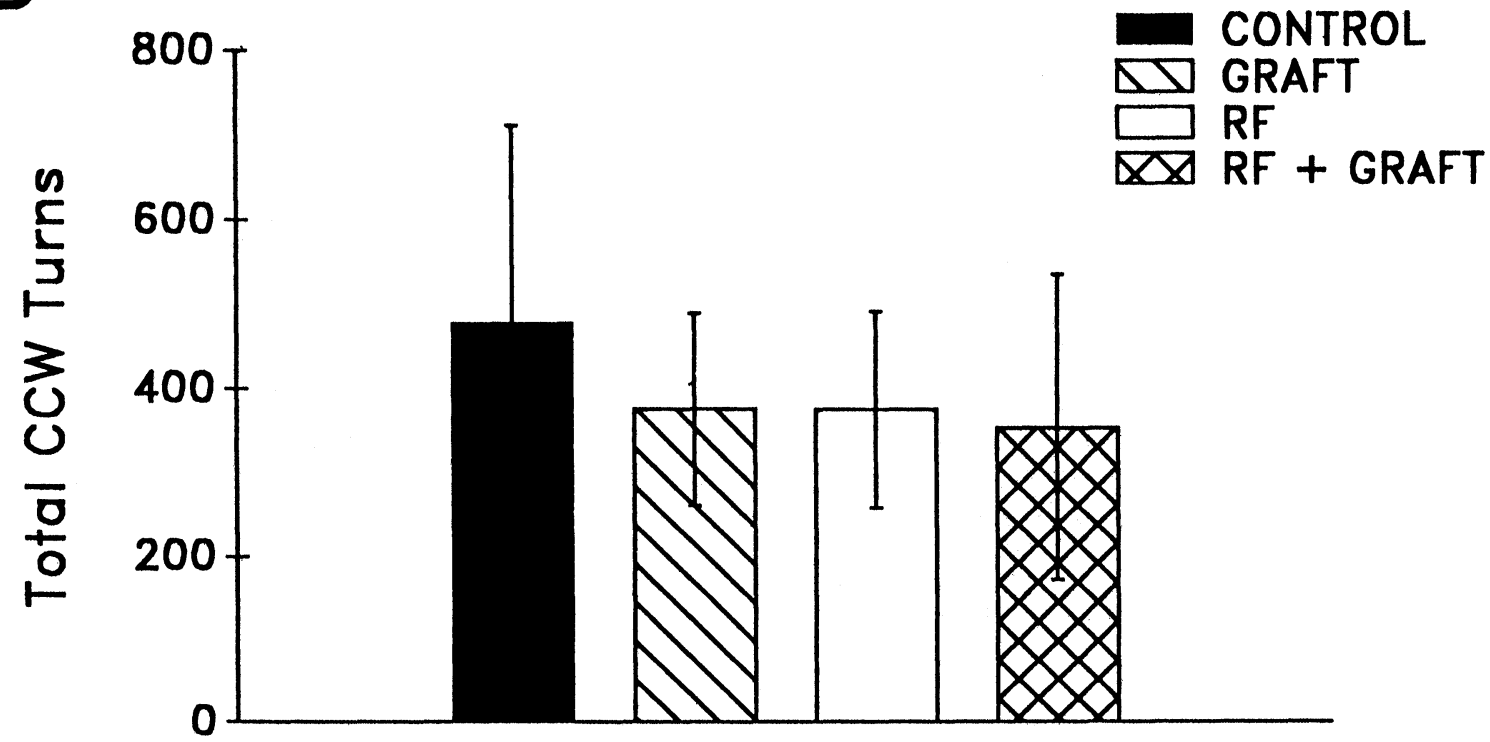

Fig. 1: A. The number of counterclockwise turns (away from the lesioned side) in response to apomorphine is shown as a function of time for all animals after the 6-OHDA lesion but before any treatment. Each point represents a two-minute epoch and is the average of all pretreatment trials. The typical, biphasic response is shown in some of the responses, with the second peak at approximately 25 minutes. B. Average total number of turns during the 60 -minute recording period is shown for the four different groups, before any treatment. The groups are not statistically different. 


\section{WEEKS AFTER TREATMENT}

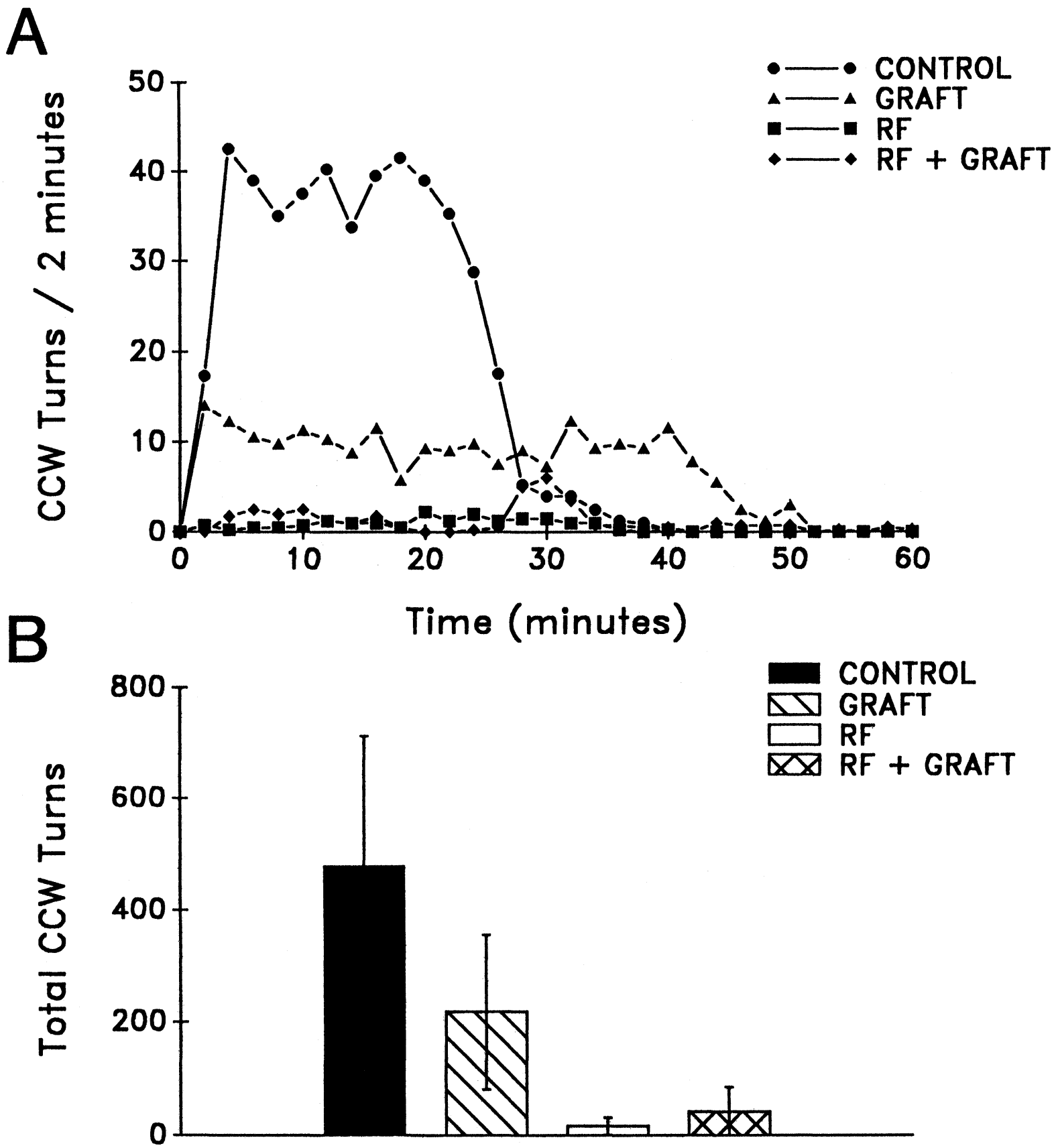

Fig. 2: A. A similar graph as in Fig. 1A at three weeks but after the different treatments as indicated. The control remains unchanged from the initial test, the graft group shows a decreased but prolonged turning response and the two lesion groups show a significant reduction in the number of turns. B. The average total number of turns is significantly decreased for both lesion groups and does not appear to be different depending upon the grafting of adrenal medulla. 


\section{WEEKS AFTER TREATMENT}

A

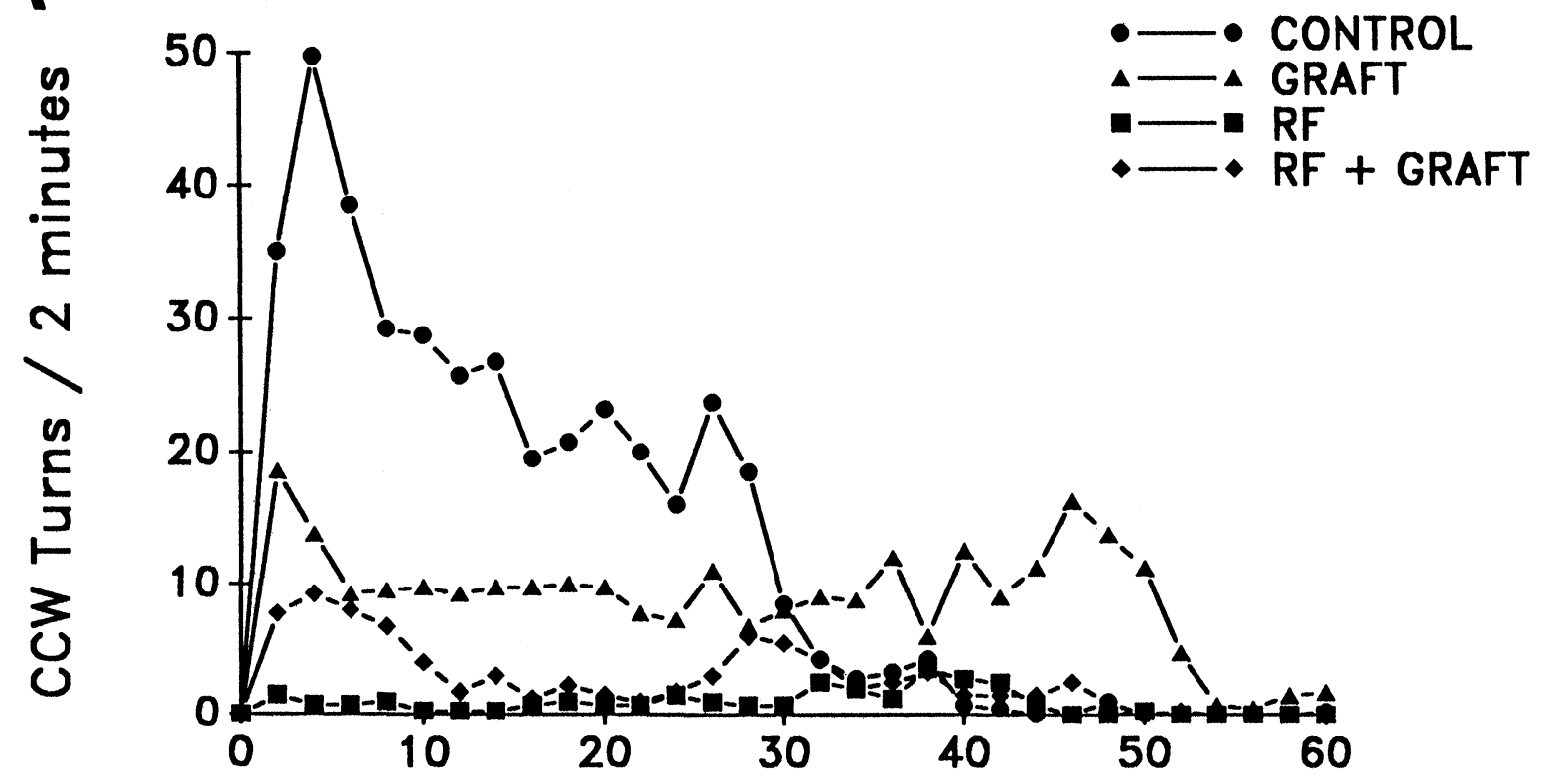

B

Time (minutes)

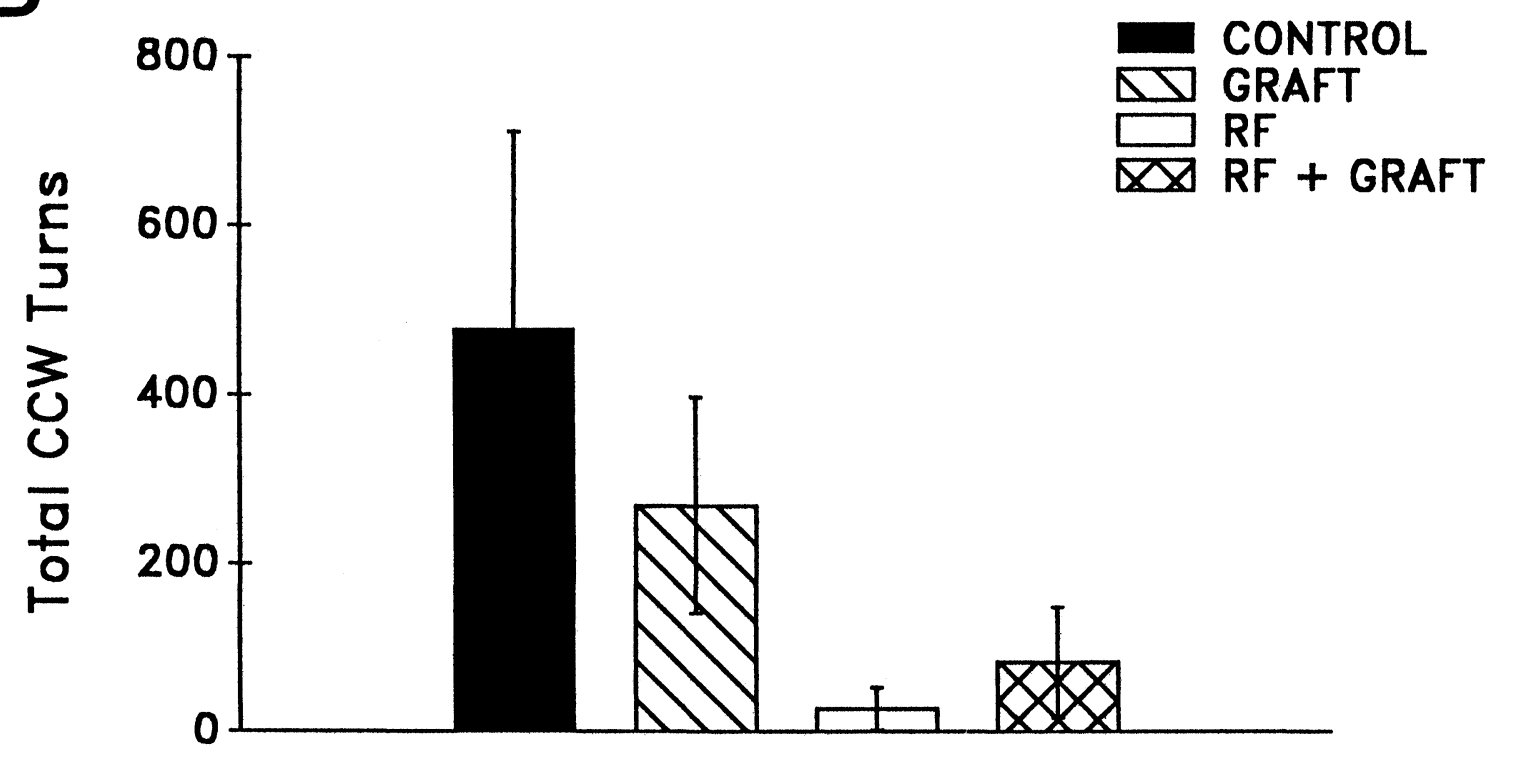

Fig. 3: Turning as a function of time (A) and average total number of turns (B) as in Fig. 2, but at five weeks following treatment. 


\section{WEEKS AFTER TREATMENT}

A
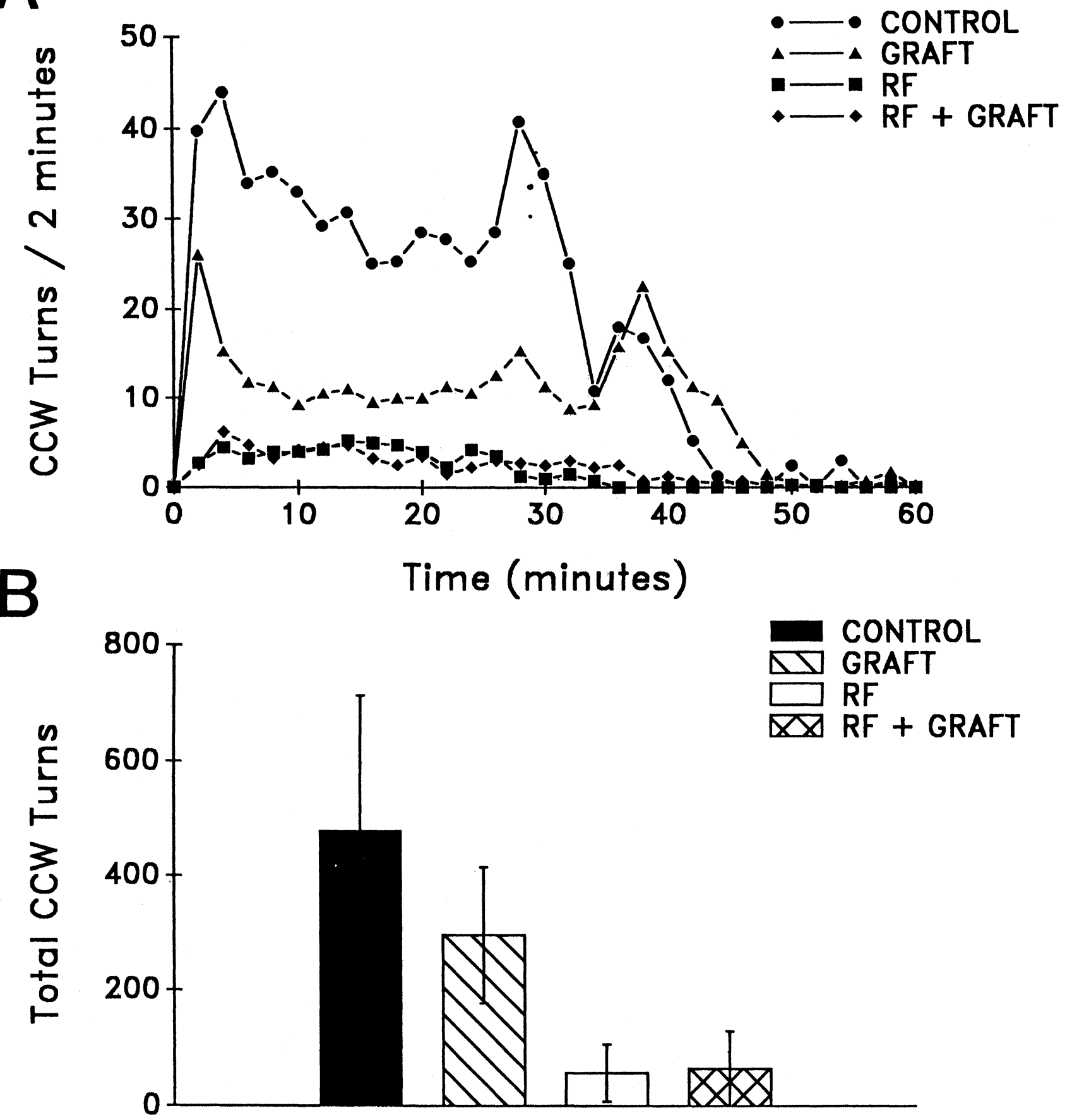

Fig. 4: Turning responses to apomorphine at seven weeks. 
compared to pretreatment control rotations at these two later times $(P>0.05)$. Animals that underwent the graft alone continued to show reduced rotations. As at three weeks, the reduction in the peak values of rotation at five and seven weeks was quite large in the first 30 minutes. Again, the prolongation of the rotational time resulted in a smaller change in total numbers of rotations for the total period of 60 minutes. Both the RF-lesioned and RF-lesioned plus graft group continued to exhibit a marked decrease in the rotational behavior. At five weeks, the reduction in total number of rotations was $92.7 \%(\mathrm{p}<.001)$ and $78.0 \%$ ( $\mathrm{p}<.001$ ) for these RF-lesioned groups, respectively, and $88.3 \%(\mathrm{p}<.001)$ and $86.8 \%(\mathrm{p}<$ .001 ) at seven weeks. The change in total number of rotations for the entire eight weeks is summarized in Fig. 5. RF-lesions produced a 92.0\% ( $p<.001)$ and RF-lesioning with graft showed a comparable level of $87.6 \%(p<.001)$ decrease in rotations. There were no significant differences between these two treatment groups which received the RF-lesion ( $p>0.05$ ). In contrast, the graft alone demonstrated only a $43.5 \%$ (p $<.05)$ reduction. Again, the total number of rotations should be interpreted in the context of the prolonged rotational time course in this group.

\section{Immunochemistry and Histology}

Histological examination based on tyrosine hydroxylase reactivity of the control animals showed a nearly complete destruction of all dopaminergic cell bodies in the pars compacta region of the substantia nigra on the side of the 6-OHDA injection when compared to the control side (Fig. 6). In addition, fluorescent fibers in the caudate-putamen complex of the same side were virtually absent. In the control group, there was no evidence of any other abnormalities except a slight lymphocytic invasion in the site of the needle tract. The other three groups (graft, RF-lesion and RFlesion + graft) showed a similar loss of tyrosine hydroxylase immunoreactivity. These findings are consistent with the rotational behavior of the animals

\section{TOTAL REDUCTION IN ROTATIONS}

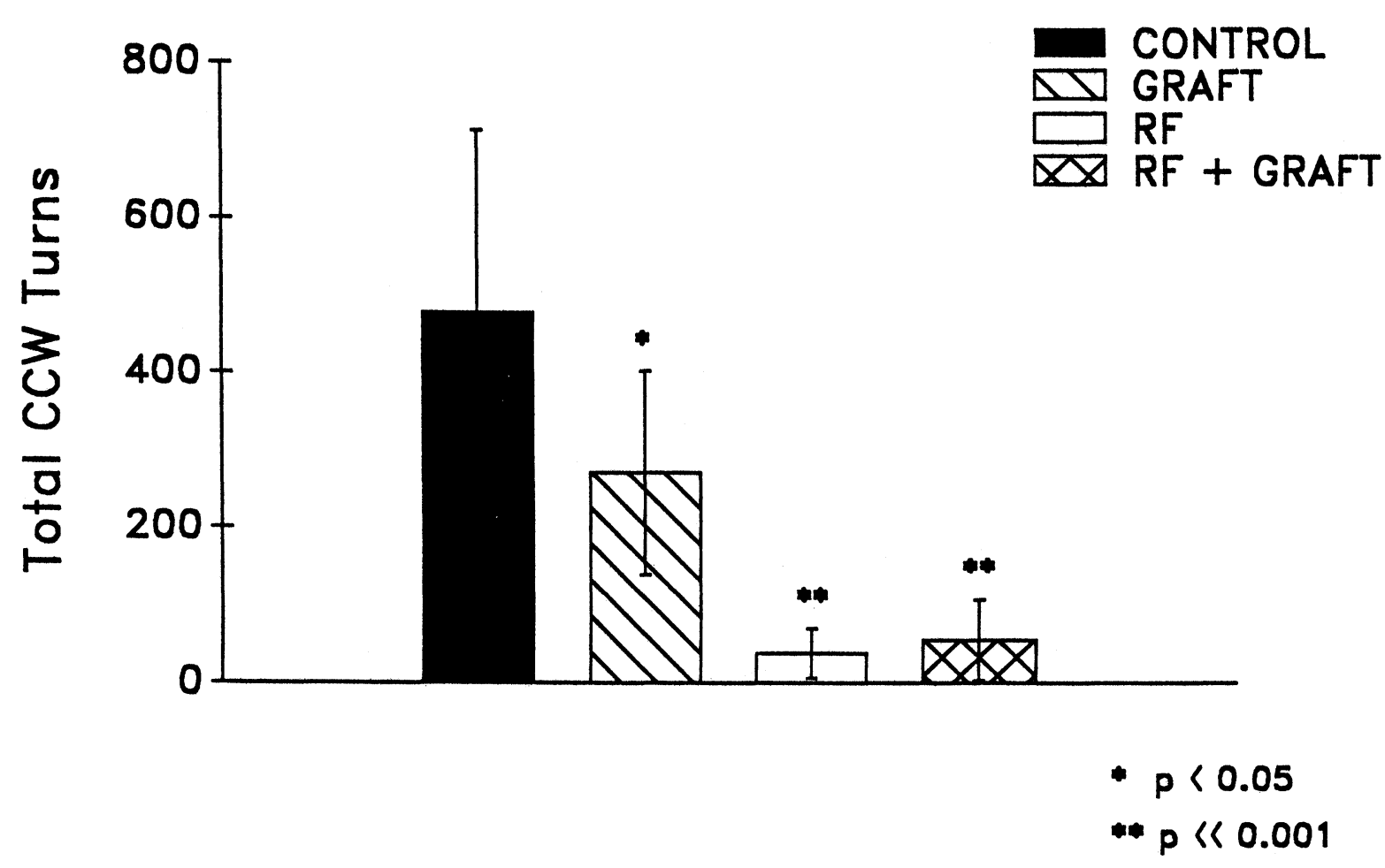

Fig. 5: Percent reduction in the total number of rotations over the entire eight weeks for all groups. 
and previous observations that extensive destruction of the dopaminergic projections from the substantia nigra is necessary to elicit the rotational behavior /49-51/.

Tyrosine hydroxylase immunohistochemistry in the transplantation group revealed the grafts as somewhat amorphous structures in the striatum (Fig. 7). The cells in the graft were only slightly fluorescent. There were between 5 and 25 intact cells per section, which possessed the round shape and size of adrenal medullary cells. Also present in the grafted animals were autofluorescent macrophages, located up to a distance of approximately 50 to $100 \mu \mathrm{m}$ from the edge of the graft. These cells were up to $40 \mu \mathrm{m}$ in diameter and appeared full of cellular debris. Only on occasion were white blood cells or inflammatory cells found, suggesting that no rejection of the heterograft occurred. In animals with only an RF-lesion on the lateral side of the cavity, there was a band of autofluorescent macrophages (Fig. 8). The combined RFlesion and transplanted animals demonstrated lesion cavities of approximately similar size to that of the animals with the RF-lesion alone, within the caudate and putamen complex. Also, the band of macrophages was found on the lateral boundary of the lesion. Adrenal medullary grafts were present in the wall of the cavity. However, the grafts were partly destroyed and replaced by phagocytes and considerable amorphous debris was also present. Surviving adrenal medullary cells were found in the wall of the cavity; these showed tyrosine hydroxylase-like reactivity similar to fresh adrenal medulla, though not as densely reactive.

\section{Lesions and Relation to Rotational Behavior}

The RF-lesions in the original series of animals destroyed an estimated $40 \%$ of the caudate-putamen complex (Fig. 9). For the example shown in Fig. 9 (Y52), the lesion was confined to the striatum, except ventro-laterally. Although the size of the cavity at this

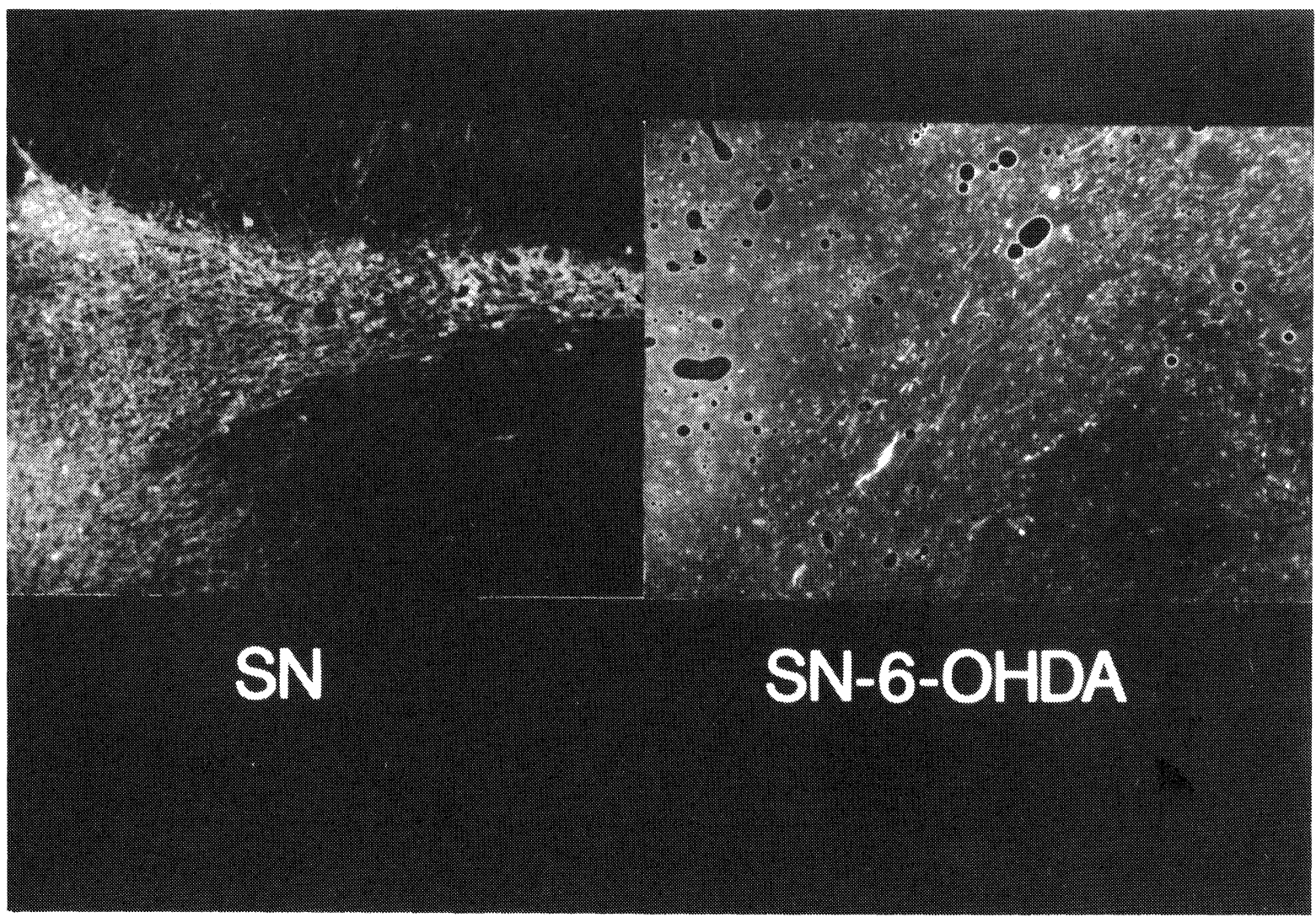

Fig. 6: A. Rat substantia nigra stained with tyrosine hydroxylase immunohistochemistry and is average of all pretreatment trials. B. The substantia nigra on the right following the 6-OHDA lesion. Note the dense loss of tyrosine hydroxylase-tike positive fibers. Scale shows $100 \mu \mathrm{m}$. 


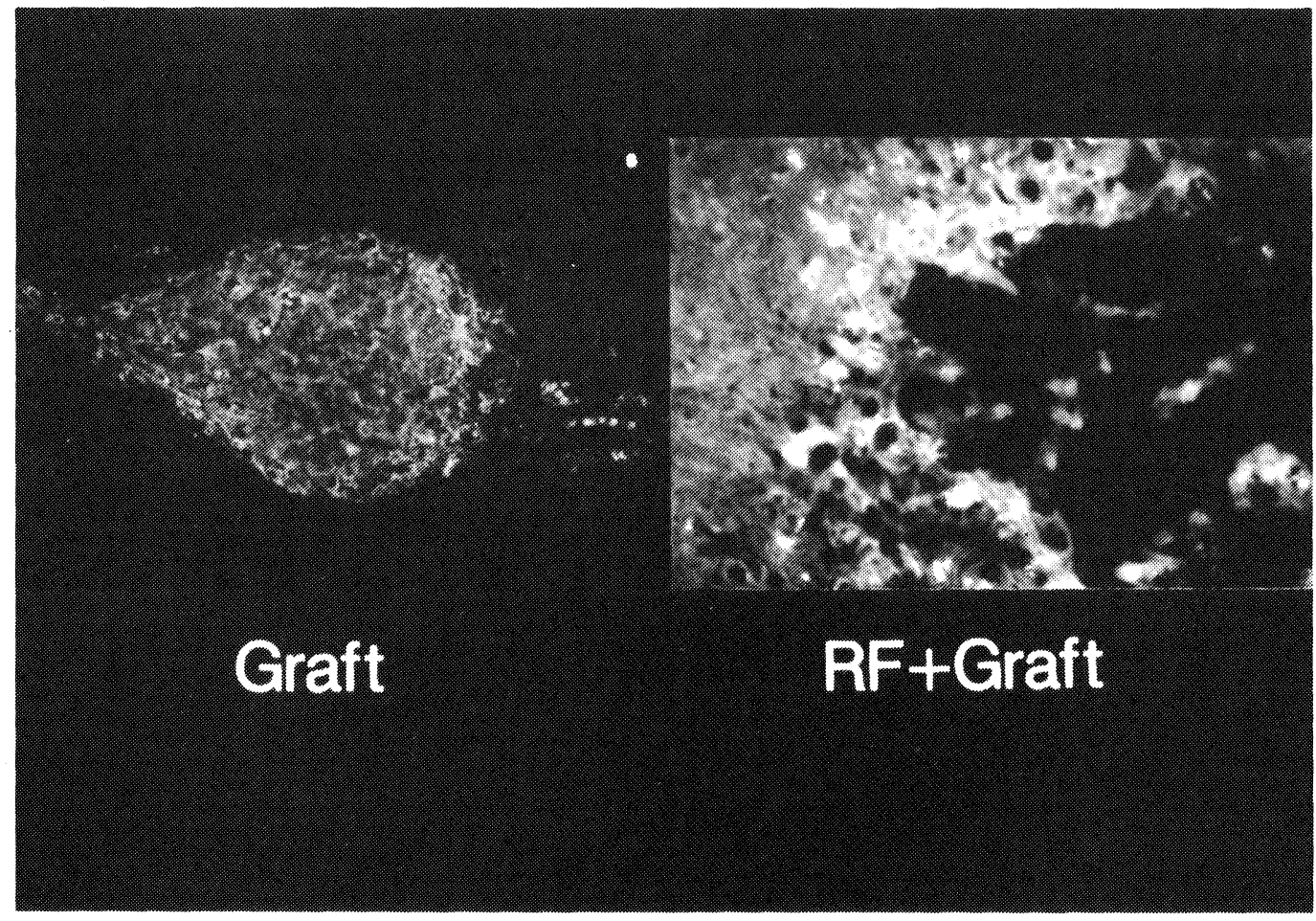

Fig. 7: A. On the left the caudate-putamen with an adrenal medulla graft at eight weeks. There is only a minimal autofluorescence from macrophages and a few surviving chromaffin cells. B. An example of adrenal medulla graft into a prelesioned cavity. On the edge of the radiofrequency lesion there was an increased number of surviving adrenal medulla cells. The scale is $100 \mu \mathrm{m}$.

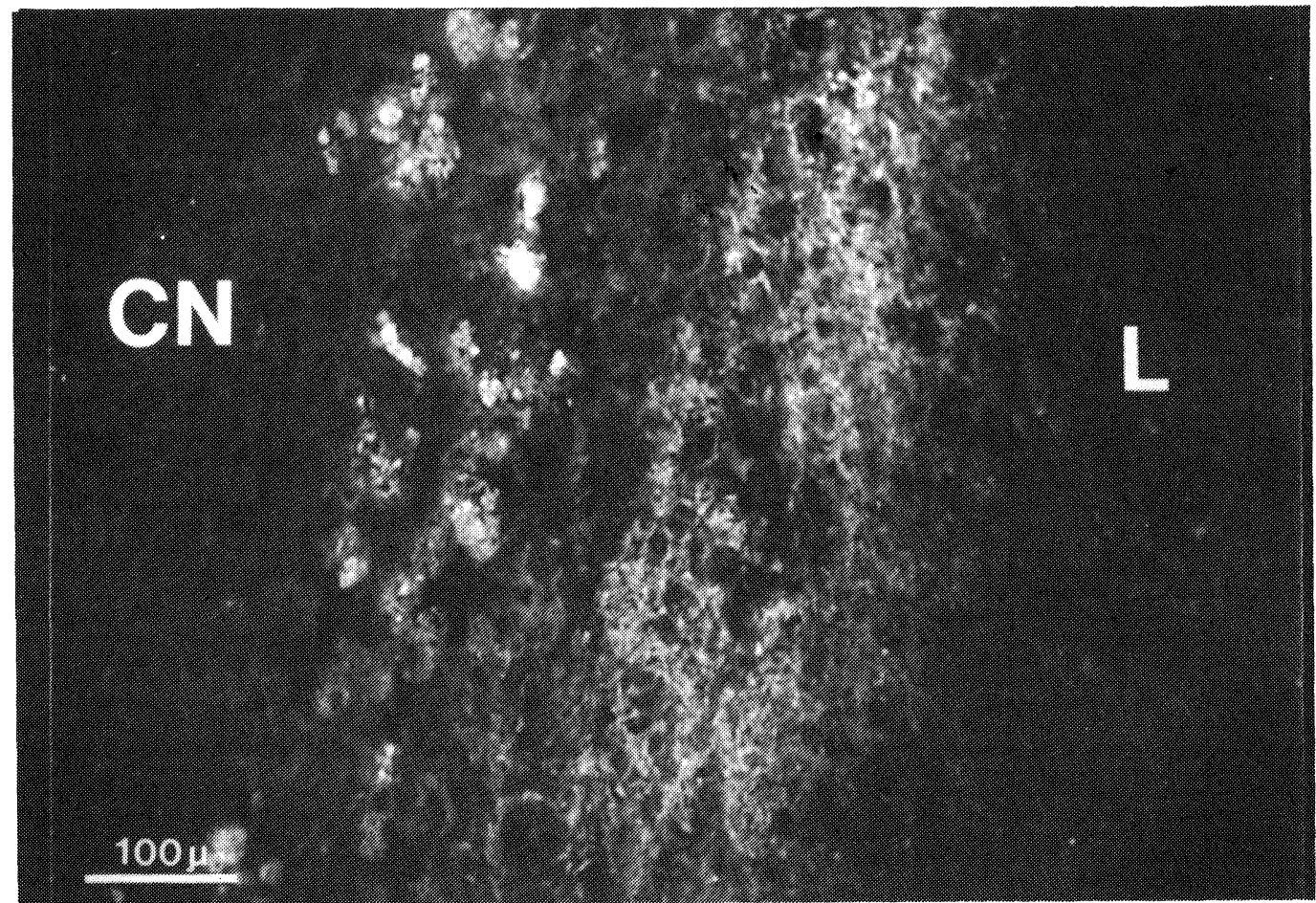

Fig. 8: Example of the increase in TH-IR reactivity in fibers next to the lesion cavity (L) in the caudate (CN). Animal had only a radiofrequency lesion without adrenal medullary graft. Increased reactivity is seen as well as autofluorescent macrophages. 
stage was not that large, there was extensive dilatation of the ipsilateral ventricle, suggesting the actual lesioned area was greater. Based on this combination of lesion cavity and ventricular dilatation, it was estimated that $40-50 \%$ of the striatum was disrupted. Similar size and location of lesions were present in the other animals. To further examine the relationship between lesioning the striatum and the changes in rotational behavior, a series of six animals was evaluated with small stereotaxic lesions in the caudateputamen complex. In this group prelesion rotational behavior was compared to the postlesion period. As in the original $2 \times 2$ design, lesions in the striatum had marked effects on the apomorphine induced rotational behavior. For the animal shown in the middle column of Fig. 9 (Y29) in which the lesion was confined primarily to the dorsal region of the striatum, a large reduction in rotations of $99 \%$ occurred. Mean prelesion rotations were $215 \pm 54$ and following the lesion $2 \pm 1$. In two additional animals with lesions in the dorsal aspects of the striatum (one similar in size, one larger), large reductions in rotations occurred
A

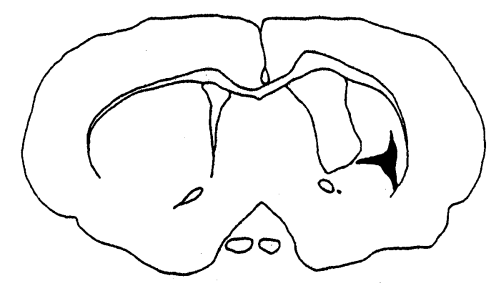

B

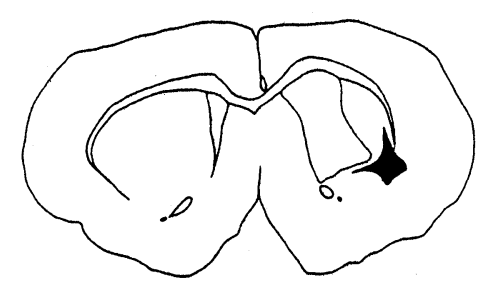

C

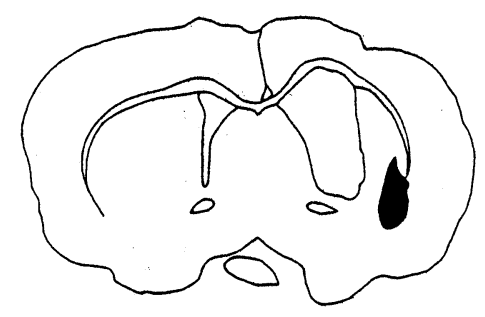

D

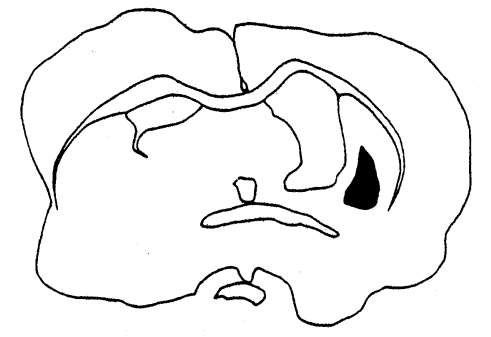

Y52
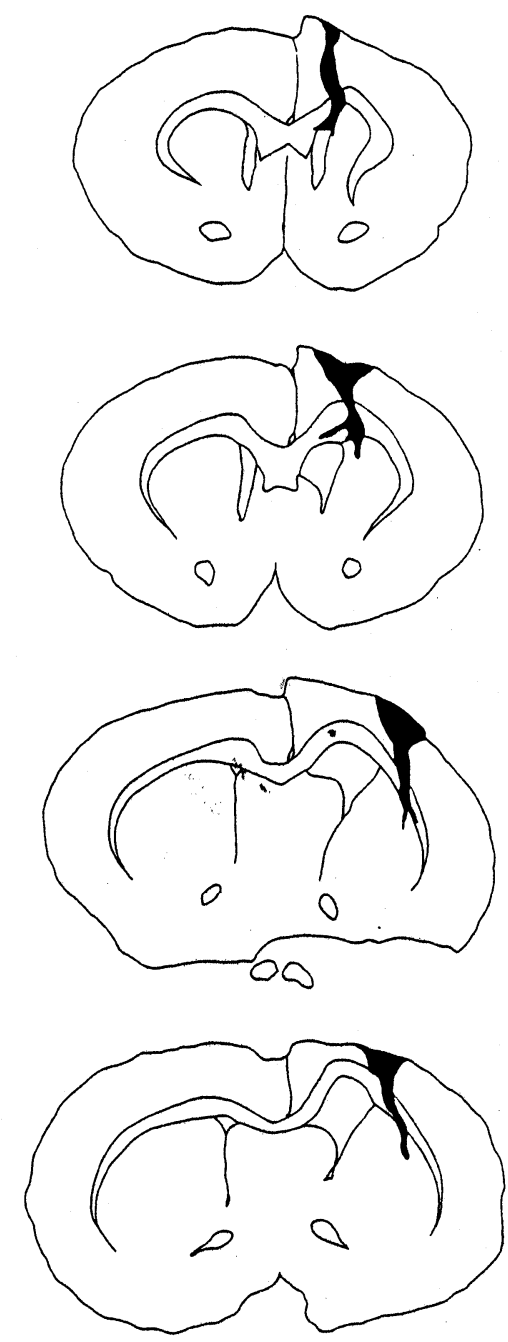

Y29
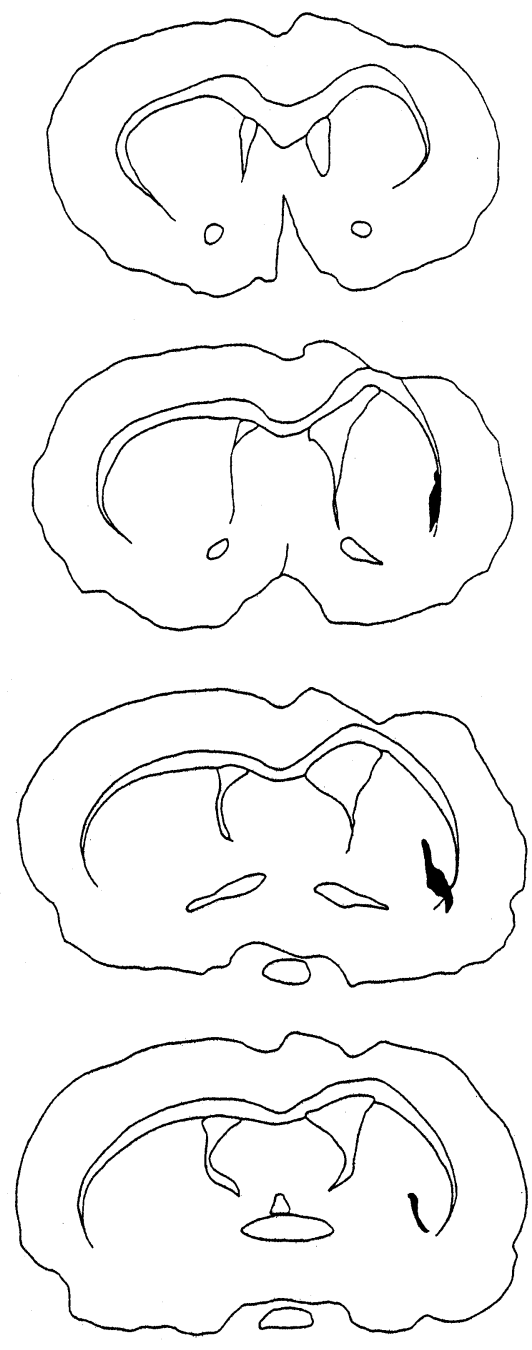

Y35

Fig. 9: Drawings of the lesioned area for three different animals at different levels ( $A$ is most anterior, $D$ most posterior). Animal on left shows typical lesion size and placement for the initial animals. Middle and right columns are examples of the smaller lesions created in the dorsal (middle) and ventral (right) striatum. Note the presence of increased ventricular size on the right, suggesting the lesion was actually larger than shown. 
(73\% and 99\%). A restricted lesion in the more ventral and lateral regions of the caudate-putamen also produced a large reduction in rotations of $39 \%$ (prelesion $=532 \pm 14.6$, postlesion $=326 \pm 74$ ). Two animals with slightly larger lesions in the same regions showed a $52 \%$ and $82 \%$ reduction $(\mathrm{p}<.01$, Student's t-test). For the six animals the average reduction was $77 \%$ ( $\mathrm{p}<.001$, Student's t-test), with the dorsal lesions averaging $90 \%(\mathrm{p}<.001)$ and the more ventral-lateral lesions averaging $56 \%(p<.01)$.

\section{DISCUSSION}

\section{Efficacy of Adrenal Medulla Grafts}

Four groups of 6-OHDA lesioned rats receiving various treatments were directly compared in terms of the behavioral outcome. The control group maintained a high level of rotation throughout the entire testing period and showed no evidence of recovery during the eight-week observation period. This persistent behavioral expression in response to the apomorphine is consistent with the immunohistochemistry (Fig. 6) and typical for 6-OHDA lesioned rats /14,49,50/. Animals receiving adrenal medulla heterografts showed a $43.5 \%$ reduction in apomorphine induced rotations up to eight weeks after transplantation, a value comparable to previous reports $/ 3,4,18-21,36,48 /$. In addition to the reduction in the total number of counterclockwise turns, the transplantation group showed a prolongation of the time period during which rotation occurred. At three, five, and seven weeks, the grafted animals completed more turns in the last 30 minutes than any other of the three groups, including the control group (Figs. 2, 3, and 4). Although not discussed or quantitated in Stromberg et al. (1985) $/ 48 /$, many of their published plots of rotation following adrenal medulla grafting show some prolongation in rotation time as well as a reduction in the number of rotations.

There are several possible mechanisms for the prolongation of rotational response after grafting of adrenal medulla. Grafted chromaffin cells may undergo a change in their catecholamine uptake, release or synthesis mechanisms. Potentially, the apomorphine may initially be sequestered by the grafted cells and then subsequently released to prolong the rotational behavior. Apomorphine itself may also promote a delayed release of catecholamines as does amphetamine, which generates a much longer time course of rotational behavior than does apomorphine after the 6-OHDA lesion (up to 240 minutes after the injection for amphetamine, as opposed to the duration of approximately 30 minutes with apomorphine; /51/). Apomorphine is known to induce both ornithine decarboxylase and tyrosine hydroxylase $/ 16 /$, potentially promoting catecholamine output from the transplanted cells. Another possibility is that the dopamine receptors in the caudate-putamen area may be significantly changed by the grafting of the adrenal medullary cells, such as a shift in the relative proportions of $D_{1}$ and $D_{2}$ receptors $/ 10,42 /$. Although the mechanism(s) remains speculative, the observation has two implications. The first is that the graft alters the dynamics of the response to apomorphine and the second is the prolongation of rotation time must be considered when evaluating adrenal medullary grafting.

\section{Enhancement of Adrenal Medulla Graft Survival}

The original goal underlying this study was to increase the survival and integration of adrenal medulla grafts into the host by using a delayed grafting approach into an RF-lesion cavity $/ 7,13,44 /$. The grafts exhibit improved cell survival when placed in the pre-existing RF-lesion cavity (Fig. 7) as compared to direct transplantation into the striatum. The unexpected but intriguing observation was that the radiofrequency cavity without graft produced a marked reduction in rotational behavior (92.0\%). Creation of a cavity was also accompanied by marked histochemical changes, including conspicuous macrophages and the presence of a tyrosine hydroxylase-like immunoreactivity (THIR), with apparent increased dopaminergic fibers at the lesion border. Several other investigators have described similar graft enhancement of TH-IR fibers in the MPTP mouse /8/ and in normal and MPTP monkeys $/ 2,17 /$. However, grafting into the cavity did not improve the behavioral outcome, as compared to the RF-lesion alone. Although we favor the concept that the enhanced immunoreactivity represents new sprouting of pre-existing dopaminergic fibers, other possibilities exist (see /4,8,17/). The cellular or humoral components for the increased TH-IR fiber network near the cavity are also unknown. Macrophages are conspicuous near the lesion and are 
known to contain a variety of trophic factors including interleukin-1 $/ 8,25,41$; see also $13 /$. Whether the macrophages contribute to the TH-IR fiber enhancement in the lesioned animals through either a direct or indirect route remains to be determined. Interleukin-1 promotes synthesis of NGF in fibroblasts and Schwann cells in the lesioned sciatic nerve /31/. Recently, it has also been shown that NGF in combination with grafts of non-neural tissue (sciatic nerve or fat) also decreases the rotational behavior of 6-OHDA rats $/ 41 /$. Together, these observations suggest that trophic mechanisms are playing a role in the increased TH-IR fiber network observed in the radiofrequency lesioned animals.

Although $40-50 \%$ of the caudate-putamen complex was destroyed in the initial phase of the present study, the lesion effect on rotation was found to be present in much smaller lesions and seemed to depend on location. In an additional six animals with much smaller lesions of the caudate-putamen, the decrease in total rotation was $77 \%$, still greater than the graft alone. However, location seems to be critical, for in three animals, small lesions restricted to the dorsolateral caudate-putamen produced dramatic suppression of the apomorphine induced rotations $(90 \%)$. This is the same region of the striatum which exhibits high concentrations of D2-dopamine supersensitive receptors after the 6-OHDA lesion $/ 10,39$, 42/. Other data also support the concept of localization of function in the rat striatum, for example midventral lesions produce greater impairment in sensorimotor orientation $/ 15 /$. Therefore, the data suggest that the effects of the RF-lesions may have considerable spatial specificity in terms of location within the striatum. Lesioning the appropriate region and receptor populations may dramatically alter the motor asymmetry.

\section{Mechanism of RF Lesion Effect}

The surgical treatment of parkinsonism has a long and colorful history, with a large number of experimental surgical procedures described /12,34/. There are several reports of temporary improvement of parkinsonian symptoms with caudate lesions /34/. However, putamen lesions have not been reported as a mode of treatment. Except for small lateral thalamic lesions, striatal lesions have not demonstrated consistent clinical efficacy, and such lesions have not been performed on humans for years due to the high risk. In the 6-OHDA rodent model of parkinsonism, this study documents that lesioning has a marked effect on one of the major motor abnormalities. A destructive or disruptive mechanism on the dopaminergic receptor population in the striatum is proposed as the underlying mechanism. Although other changes are seen with caudate-putamen lesions, the rotational behavior in response to apomorphine seems to reflect changes exclusively in the receptor populations $/ 5 /$. A non-specific mechanism must be considered when interpreting the grafting or other destructive manipulations of the striatum in animal models of parkinsonism or in the human $/ 1,4,8,19,29$, $30,32,33,37,41,47,48 /$. Some of the improvement of motor asymmetry in the animal models of parkinsonism following grafting of adrenal medulla may be due to disruption of the striatum, which necessarily occurs with any surgical procedure, stereotactic or open. This nonspecific destruction phenomenon may be especially effective if select areas are lesioned such as dorsolateral caudate-putamen in the rat. Whether striatal lesions in primates would result in a similar degree of change in extremity movements remains to be determined.

\section{ACKNOWLEDGEMENTS}

This work was supported by the Minnesota Medical Foundation, The Russell Sabor Foundation and Mr. Hal Seth. R. Parker was funded by an American Association of Neurological Surgeons Research Fellowship. We appreciate the generous help of C. Ojakangas and Dr. P. Camarata. We also wish to thank Michael McPhee for preparation of the illustrations and Linda Christensen for typing the manuscript.

\section{REFERENCES}

1. Backlund EO, Grandberg PO, Hamberger B, Sedvall G, Seiger A, Olson L. Transplantation of adrenal medullary tissue to striatum in Parkinsonism. In A Bjorklund, U Stenevi (Eds.), Neural grafting in the mammalian CNS. Amsterdam: Elsevier, 1985, pp. 551556. 
2. Bankiewicz KS, Plunkett RJ, Kopin IJ, Jacobowitz DM, London WT, Oldfield EH. Transient behavioral recovery in hemiparkinsonian primates after adrenal medullary allografts. In DM Gash and JR Sladek, Jr. (Eds.). Progress in brain research, Vol. 78. Amsterdam: Elsevier, 1988, pp. 543-549.

3. Becker JB, Freed WJ. Adrenal medulla grafts enhance functional activity of the striatal dopamine system following substantia nigra lesions. Brain Res 1988; 462:401-406.

4. Bing G, Notter MFD, Hansen JT, Gash DM. Comparison of adrenal medullary, carotid body and PC12 cell grafts in 6-OHDA lesioned rats. Brain Res Bull 1988; 20:399-406.

5. Bjorklund A, Dunnett SB, Stenevi U, Lewis ME, Iversen SD. Reinnervation of the denervated striatum by substantia nigra transplants: Functional consequences as revealed by pharmacological and sensorimotor testing. Brain Res 1980; 199:307-333.

6. Bjorklund $\mathrm{A}$, Lindvall $\mathrm{O}$, Isacson $\mathrm{O}$, Brundin $\mathrm{P}$, Wictorin K, Strecker RE, Clarke DJ, Dunnett SB. Mechanisms of action of intracerebral neural implants: Studies on nigral and striatal grafts to the lesioned striatum. Trends in Neurosci 1987; 10:509-516.

7. Bjorklund A, Stenevi U. Intracerebral neural implants: Neuronal replacement and reconstruction of damaged circuitries. Ann Rev of Neurosci 1984; 7:279-308.

8. Bohn MC, Cupit L, Marciano F, Gash DM. Adrenal medulla grafts enhance recovery of striatal dopaminergic fibers. Science 1987; 237:913-916.

9. Brundin P, Strecker RE, Widner H, Clarke DJ, Nilsson OG, Astedt B, Lindvall O, Bjorklund A. Human fetal dopamine neurons grafted in a rat model of Parkinson's disease: Immunological aspects, spontaneous and druginduced behavior, and dopamine release. Exp Brain Res 1988; 70:192-208.

10. Buonamici M, Caccia M, Carpentier M, Pegrassi L, Rossi AC, Di Chiara D. D-1 receptor supersensitivity in the rat striatum after unilateral 6-hydroxydopamine lesions. Eur J of Pharmacol 1986; 126:347-348.

11. Burns RS, Chiueh CC, Markey SP, Ebert MH, Jacobowitz DM, Kopin IJ. A primate model of Parkinsonism: Selective destruction of dopaminergic neurons in the pars compacta of the substantia nigra by N-methyl-4-phenyl-1,2,3,6-tetrahydro-pyridine. Proc Natl Acad Sci USA 1983; 80:4546-4550.

12. Cooper IS, Bravo GJ. Implications of a five-year study of 700 basal ganglia operations. Neurology 1958; 8:701707.

13. Cotman CW, Kesslak JP. The role of trophic factors in behavioral recovery and integration of transplants. In DM Gash and JR Sladek (Eds.), Progress in brain research, Vol. 78. Amsterdam: Elsevier, pp. 311-319.

14. Dravid A, Jaton AL, Enz A, Frei P. Spontaneous recovery from motor asymmetry in adult rats with 6hydroxydopamine-induced partial lesions of the substantia nigra. Brain Res 1984; 311:361-365.
15. Dunnett SB, Bjorklund A, Stenevi U, Iversen SD. Grafts of embryonic substantia nigra reinnervating the ventrolateral striatum ameliorate sensorimotor impairments and akinesia in rats with 6-OHDA lesions of the nigrostriatal pathway. Brain Res 1981; 229:209217.

16. Ekker M, Sourkes TL. Differential effects of thioridazine, clozapine and metoclopramide on the induction of adrenomedullary enzymes by apomorphine. Neuropharmacol 1985; 24:1063-1066.

17. Fiandaca, MD, Kordower, JH, Hansen JT, Jiao, S-S, Gash DM. Adrenal medullary autografts into the basal ganglia of cebus monkeys: Injury-induced regeneration. Exp Neurol 1988; 102:76-91.

18. Fitzgerald LR, Glick SD, Schneider AS. Effect of striatal implantation of bovine adrenal chromaffin cells on turning behavior in a rat model of Parkinson's disease. Brain Res 1989; 481:373-377.

19. Freed WJ. Functional brain tissue transplantation: Reversal of lesion-induced rotation by intraventricular substantia nigra and adrenal medulla grafts, with a note on intracranial retinal grafts. Biol Psych 1983; 18:12051267.

20. Freed WJ, Cannon-Spoor HE, Krauthamer E. Intrastriatal adrenal medulla grafts in rats: Long-term survival and behavioral effects. J Neurosurg 1986; 65:664-670.

21. Freed WJ, Morihisa JM, Spoor E, Hoffer BJ, Olson L, Seiger A, Wyatt RJ. Transplanted adrenal chromaffin cells in rat brain reduce lesion-induced rotational behaviour. Nature 1981; 292:351-352.

22. Freed WJ, Perlow MJ, Karoum F, Seiger A, Olson L, Hoffer BJ, Wyatt RJ. Restoration of dopaminergic function by grafting of fetal rat substantia nigra to the caudate nucleus: Long-term behavioral, biochemical and histochemical studies. Ann Neurol 1980; 8:510-519.

23. Friehs GM, He LS, Parker RG, Ojakangas CL, Turner DA, Haines SJ, Ebner TJ. Comparison of caudate lesioning and adrenal medulla grafting in 6-OHDA rats. Soc Neurosci Abstr 1989; 15:490.

24. Gage, FH, Wolff JA, Rosenberg MB, Xu L, Yee JK, Shults C, Friedmann T. Grafting genetically modified cells to the brain: Possibilities for the future. Neurosci 1987; 23:795-807.

25. Hansen JT, Bing G, Notter MFD, Kordower JH, Fiandaca MS, Gash DM. Adrenal chromaffin cells as transplants in animal models of Parkinson's disease. J Electron Microscopy Technique 1989; 12:308-315.

26. Hansen JT, Korkower JH, Fiandaca MS, Jiao S-S, Notter MFD, Gash DM. Adrenal medullary autografts into the basal ganglia of cebus monkeys: Graft viability and fine structure. Exp Neurol 1988; 102:65-75.

27. Herrera-Marschitz $M$, Forster $C$, Ungerstedt $U$. Rotational behavior elicited by intracerebral injections of apomorphine and pergolide in 6-hydroxy-dopaminelesioned rats. I: Comparison between systemic and intrastriatal injections. Acta Physiol Scand 1985; 125:519-527. 
28. Herrera-Marschitz M, Stromberg I, Olsson D, Ungerstedt U, Olson L. Adrenal medullary implants in the dopamine-denervated rat striatum. II: Acute behavior as a function of graft amount and location and its modulation by neuroleptics. Brain Res 1984; 297:5361.

29. Kamo H, Kim SU, McGeer PL, Shin DH. Functional recovery in a rat model of Parkinson's disease following transplantation of cultured human sympathetic neurons. Brain Res 1986; 397:372-376.

30. Kamo H, Kim SU, McGeer PL, Shin DH. Transplantation of cultured fetal human adrenal chromaffin cells to rat brain. Neurosci Lett. 1985; 57:4348.

31. Lindholm $D$, Heumann $R$, Meyer $M$, Thoenen $H$. Interleukin-1 regulates synthesis of nerve growth factor in non-neuronal cells of rat sciatic nerve. Nature 1987; 330:658-659.

32. Lindvall O, Backlund E-O, Farde L, Sedvall G, Freedman R, Hoffer B, Nobin A, Seiger A, Olson L. Transplantation in Parkinson's disease: Two cases of adrenal medullary grafts to the putamen. Ann Neurol 1987; 22:457-468.

33. Madrazo I, Drucker-Colin R, Diaz V, Martinez-Malta $\mathrm{J}$, Torres C, Becerril JJ. Open microsurgical autograft of adrenal medulla to the right caudate nucleus in two patients with intractable Parkinson's disease. $\mathrm{N}$ Engl J Med 1987; 316:831-834.

34. Meyers R. Surgical experiments in the therapy of certain 'extrapyramidal' diseases: A current evaluation. Acta Psych Neurol Suppl 1951; 67:6-42.

35. Morihisa JM, Nakamura RK, Freed WJ, Mishkin M, Wyatt RJ. Adrenal medulla grafts survive and exhibit catecholamine-specific fluorescence in the primate brain. Exp Neurol 1984; 84:643-653.

36. Nishino H, Ono T, Shibata R, Kawamata S, Watenabe H, Shiosaka S, Tohyama M, Karadi Z. Adrenal medullary cells transmute into dopaminergic neurons in dopamine-depleted rat caudate and ameliorate motor disturbances. Brain Res 1988; 445:325-337.

37. Patel-Vaidya U, Wells MR, Freed WJ. Survival of dissociated adrenal chromaffin cells of rat and monkey transplanted into rat brain. Cell Tissue Res 1985; 240:281-285.

38. Paxinos G, Watson C. The rat brain. Sydney: Academic Press, 1986.

39. Perese DA, Ulman J, Viola J, Ewing SE, Bankiewicz KS. A 6-hydroxydopamine-induced selective parkinsonian rat model. Brain Res 1989; 494:285-293.

40. Perlow MJ, Freed WJ, Hoffer BJ, Seiger A, Olson L, Wyatt RJ. Brain grafts reduce motor abnormalities produced by destruction of nigrostriatal dopamine system. Science 1979; 204:643-647.

41. Pezzoli G, Fahn S, Dwork A, Truong DD, de Yebenes JG, Jackson-Lewis V, Herbert J, Cadet JL. Nonchromaffin tissue plus nerve growth factor reduces experimental Parkinsonism in aged rats. Brain Res 1988 459:398-403.

42. Savasta M, Dubois A, Benavides J, Scatton B. Different plasticity changes in D1 and D2 receptors in rat striatal subregions following impairment of dopaminergic transmission. Neurosci Lett 1988; 85:119-124.

43. Sladek JR, Jr, Redmond DE, Collier TJ, Haber SN, Elsworth JD, Deutsch AY, Roth RH. Transplantation of fetal dopamine neurons in primate brain reverses MPTP induced Parkinsonism. In FJ Seil, E Herbert, BM Carlson (Eds.), Progress in brain research, Vol. 71. Amsterdam: Elsevier, 1987, pp. 309-323.

44. Stenevi U, Bjorklund A, Svendgaard N-A. Transplantation of central and peripheral monoamine neurons to the adult rat brain: Techniques and conditions for survival. Brain Res 1976; 114:1-20.

45. Strecker RE, Sharp T, Brundin P, Zetterstrom T, Ungerstedt $\mathrm{U}$, Bjorklund A. Autoregulation of dopamine release and metabolism by intrastriatal nigral grafts as revealed by intracerebral dialysis. Neurosci 1987; 22:169-178.

46. Stromberg I, Bygdeman M, Goldstein M, Seiger A, Olson L. Human fetal substantia nigra grafted to the dopamine-denervated striatum of immunosuppressed rats: Evidence for functional reinnervation. Neurosci Lett 1986; 71:271-276.

47. Stromberg I, Herrera-Marschitz M, Hultgren $L$ Ungerstedt $\mathrm{U}$, Olson L. Adrenal medullary implants in the dopamine-denervated rat striatum. I. Acute catecholamine levels in grafts and host caudate as determined by HPLC-electrochemistry and fluorescence histochemistry image analysis. Brain Res 1984; 297:4151.

48. Stromberg I, Herrera-Marschitz $M$, Ungerstedt U, Ebendal T, Olson L. Chronic implants of chromaffin tissue into the dopamine-denervated striatum. Effects of NGF on graft survival, fiber growth and rotational behavior. Exp Brain Res 1985; 60:335-349.

49. Ungerstedt U. Postsynaptic supersensitivity after 6hydroxydopamine induced degeneration of the nigrostriatal dopamine system. Acta Physiol Scand Suppl 1971; 367:69-93.

50. Ungersted $U$. Stereotaxic mapping of the monoamine pathways in the rat brain. Acta Physiol Scand Suppl 1971; 367:1-47.

51. Ungerstedt $\mathrm{U}$, Arbuthnott GW. Quantitative recording of rotational behavior in rats after 6-hydroxydopamine lesions of the nigrostriatal dopamine system. Brain Res $1970 ; 24: 485-493$

52. Ungerstedt $U$, Herrera-Marschitz $M$. Behavioural pharmacology of dopamine receptor mechanisms. In L Stjarne, P Hedqvist, H Lagercrantz, A Wennmalm (Eds.), Chemical neurotransmission: 75 years, Vol. 42. New York: Academic Press, 1981, pp. 481-494. 

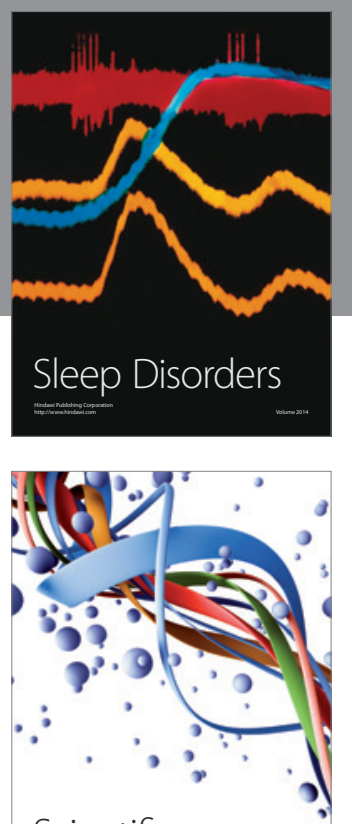

Scientifica
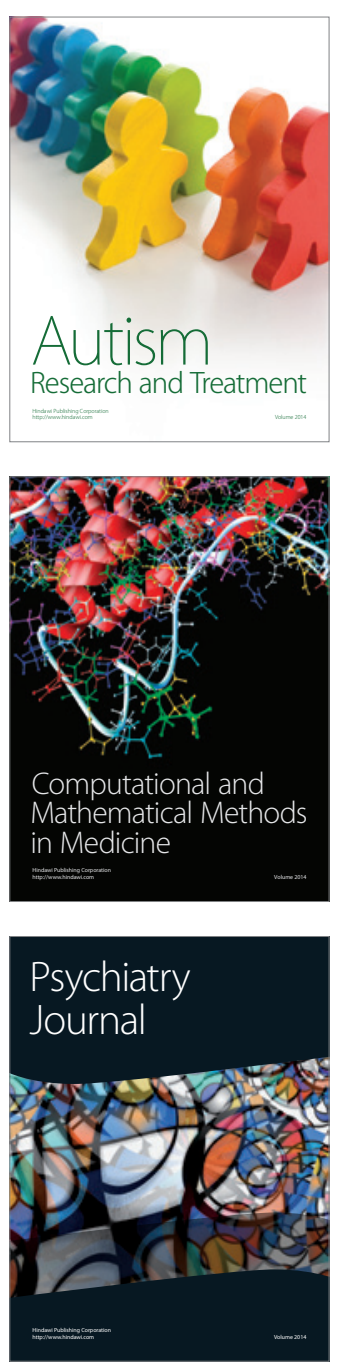
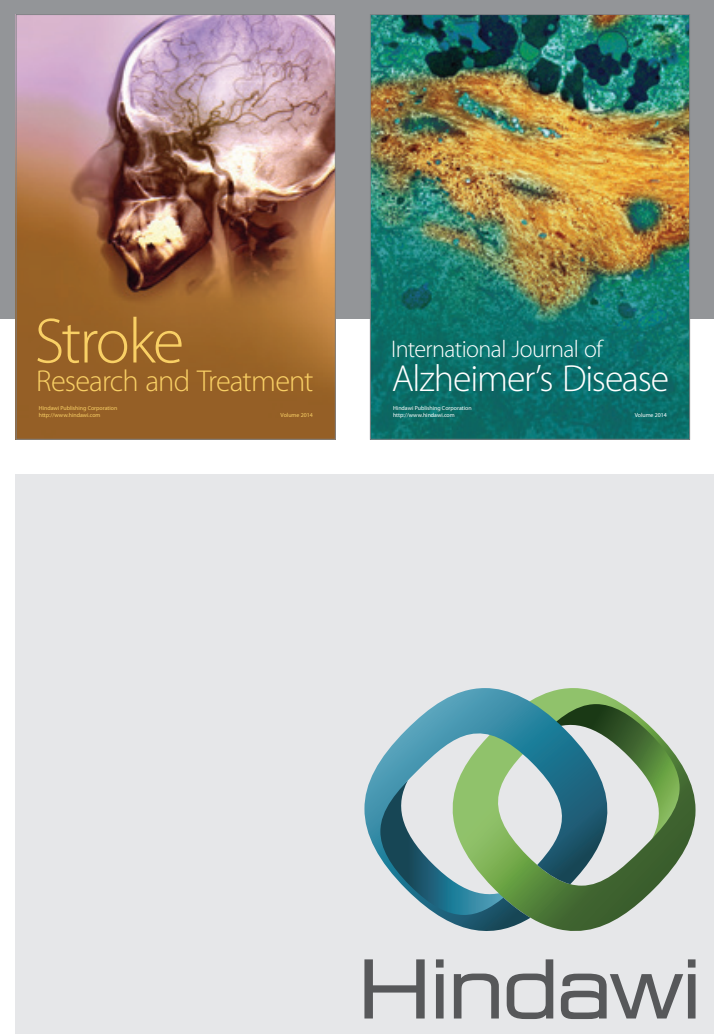

Submit your manuscripts at

http://www.hindawi.com
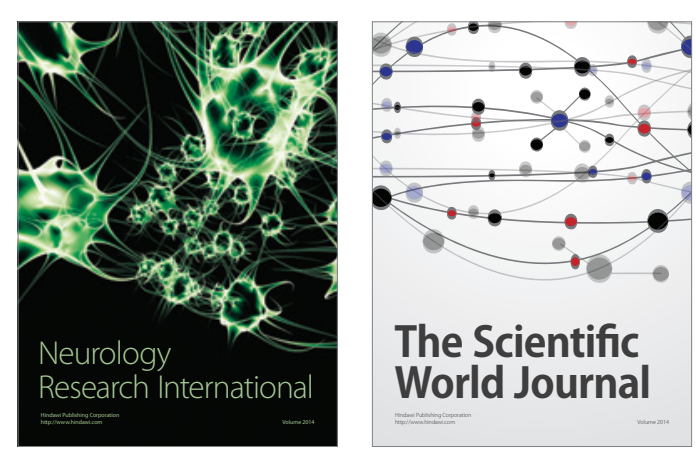

The Scientific World Journal

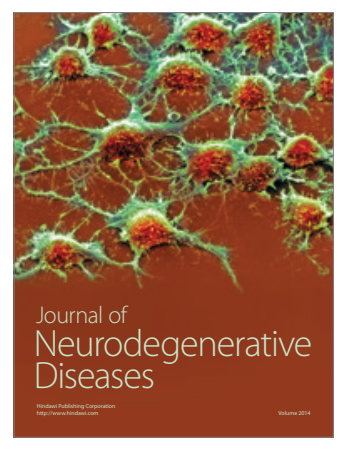

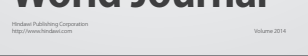

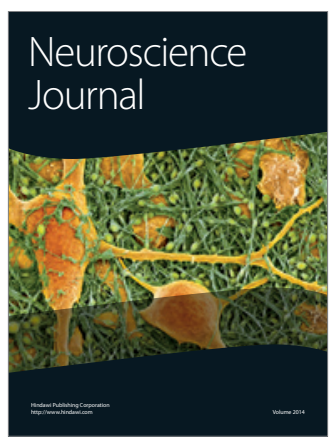

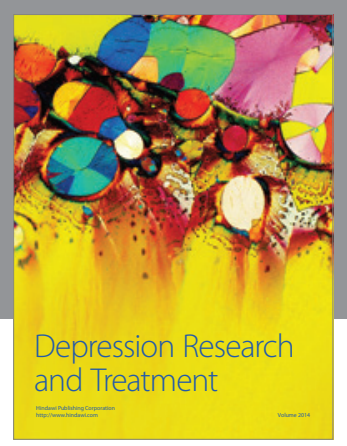
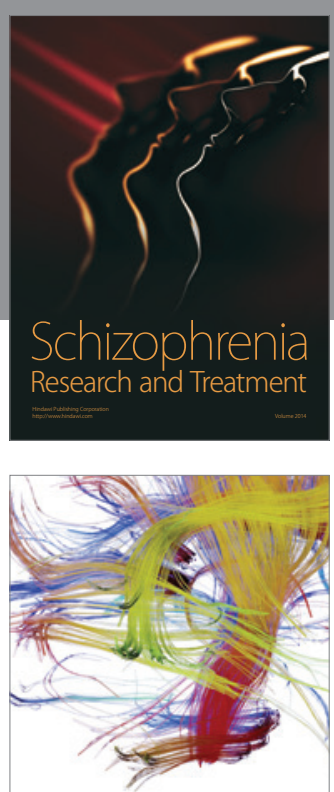

Brain Science

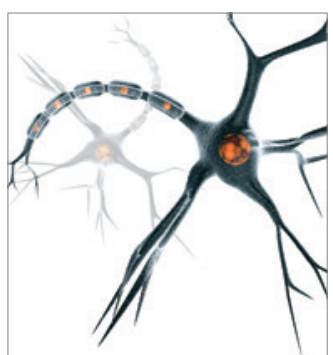

Neural Plasticity
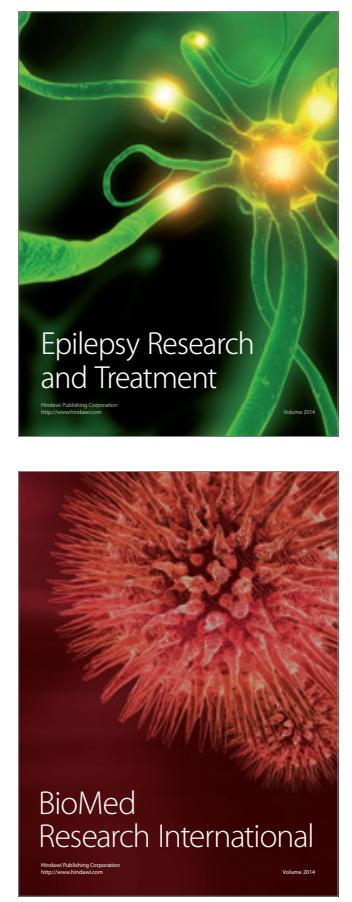

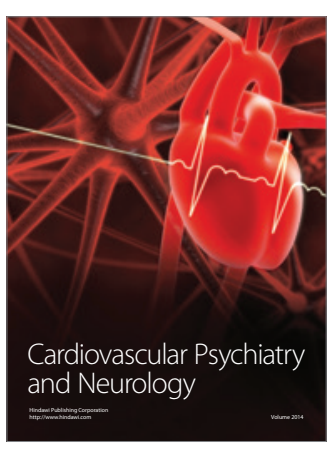

Parkinson's

Disease
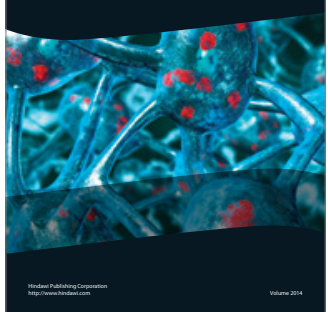